\title{
ACID AND INTERMEDIATE INTRUSIONS, DEFORMATION AND GNEISS FORMATION, NORTH-EAST OF FISKENÆSSET
}

\author{
John S. Myers
}

The sequence of acid and intermediate intrusions and of deformation provides the chronological framework of the geology of an area of $500 \mathrm{~km}^{2}$ north of inner Fiskenæsfjorden and around inner Grædefjord (Plate 1).

The oldest recognisable rocks are amphibolites and ultramafite derived from volcanics, irregular doleritic intrusions and layered, gravity-stratified sills; metasediments, chiefly quartz+biotite \pm garnet \pm sillimanite \pm magnetite gneisses; and layered, gravity-stratified bodies of anorthosite, leucogabbro and gabbro. These rocks were already partly deformed before the sequence of acid and intermediate igneous intrusions and deformation described below and summarised in Table 1.

Table 1. Simplified sequence of early Precambrian intrusions and deformations in order of increasing age

\begin{tabular}{ll}
\hline \multicolumn{1}{c}{ Intrusions } & Deformations \\
\hline Pegmatite veins & $F_{3}$ \\
\hline Qánguartoq granite, granodiorite and & $F_{2}$ \\
tonalite plutons and dykes & \\
\hline Layered tonalite-diorite-ultramafic sheets and dykes \\
Ilivertalik porphyritic granite plutons and sheets \\
Tonalite-diorite plutons \\
\hline Basic dykes \\
\hline Grodefjord granodiorite gneiss sheets \\
\hline Amphibolites mainly derived from metavolcanics, \\
metasediments and layered anorthosite sheets, \\
were already partly deformed and metamorphosed \\
\hline
\end{tabular}




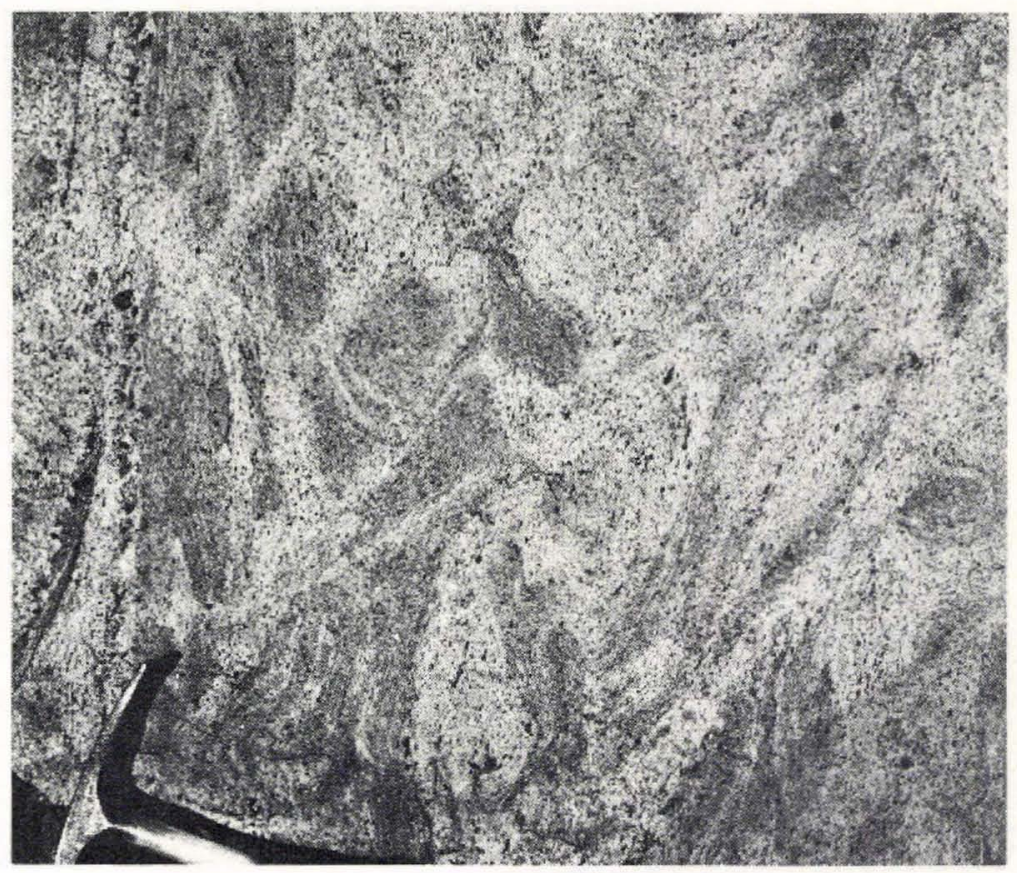

Fig. 1. Grædefjord granodiorite gneiss in a region of low total deformation, showing igneous structure with irregular coarse and finer grained patches.

\section{Grædefjord granodiorite gneiss}

This makes up the largest part of the quartzo-feldspathic gneiss of the region and is here informally given the lithostratigraphic name Grædefjord gneiss. It is typically either pegmatite-banded or schlieren-banded and consists of quartz, plagioclase, biotite and potash feldspar with accessory allanite, epidote and ilmenite. It is generally granodiorite in composition but locally it grades into tonalite, and schlieren are marked by differences in grain size and colour index.

In low deformation zones, the schlieren-banding is seen to be derived from irregular coarse and finer grained patches with gradational contacts (fig. 1), and the pegmatitebanded gneiss is seen to be derived from a porphyritic granodiorite crossed by a network of leucocratic veins $1-2 \mathrm{~cm}$ thick with sharp contacts (fig. 2). The porphyritic granodiorite is characterised by white and pink spots which are prolate ellipsoidal aggregates of plagioclase (typically $5 \times 10 \mathrm{~mm}$ ) and were probably derived from primary magmatic plagioclase phenocrysts. When these rocks are followed into more highly deformed areas, it can be seen that the coarse and finer grained patches were progressively brought into parallelism while the aggregates of plagioclase became disc-shaped ellipsoids. In areas of intense deformation and recrystallisation, the coarse and finer grained patches and leucocratic veins were attenuated, the plagioclase aggregates were streaked out, and the rocks became schlieren-banded (fig. 3) or pegmatite-banded (fig. 4) gneisses.

On a regional scale the original granodiorite appears to have been fairly uniform in character and has a colour index of 5 and now contains either biotite or locally hyper- 


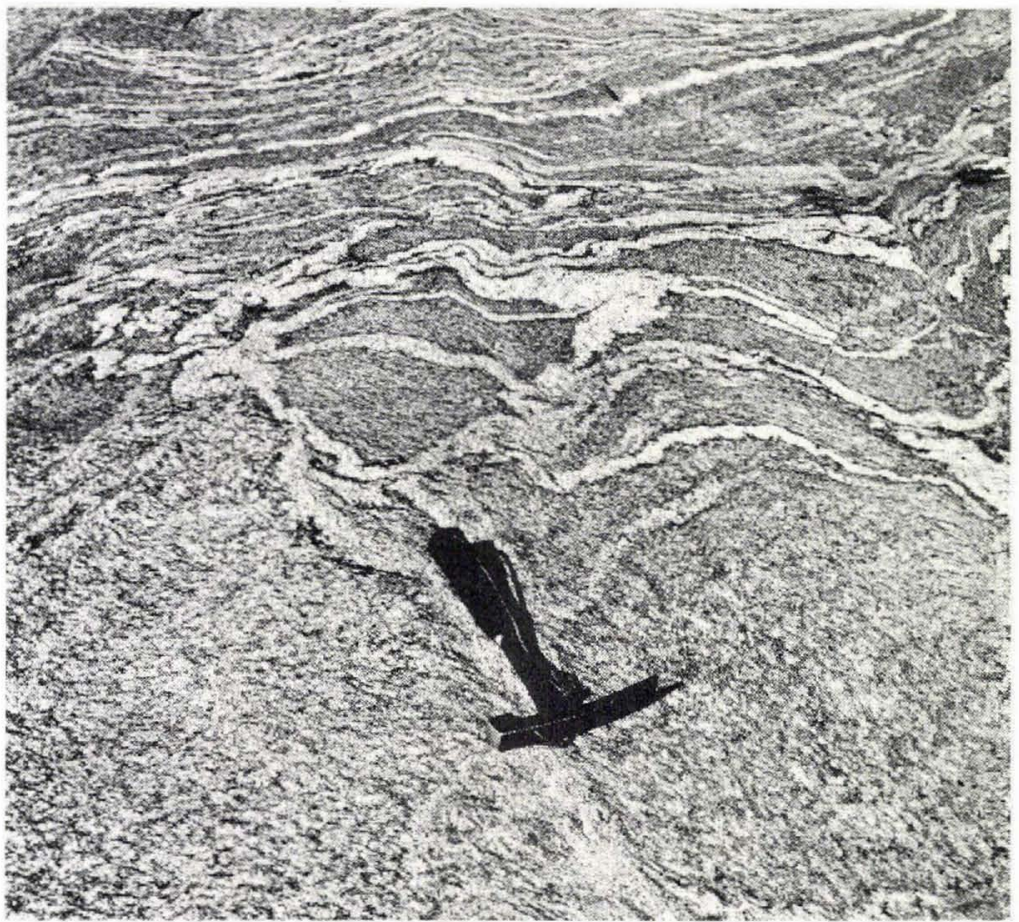

Fig. 2. Grædefjord granodiorite gneiss showing relict igneous porphyritic texture and an irregular network of leucocratic veins which are increasingly deformed and brought into parallelism towards the top of the photograph.

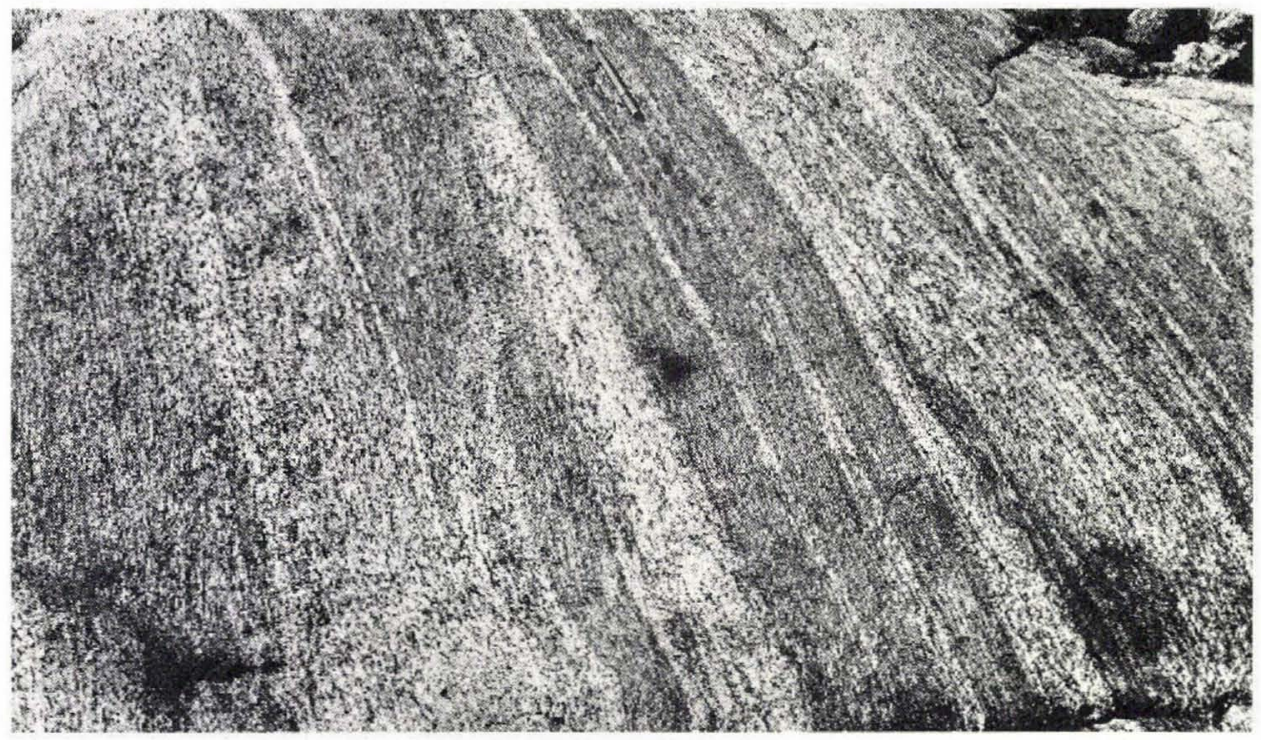

Fig. 3. Grædefjord gneiss showing relict igneous texture and schlieren banding formed by deformation of coarse and finer grained patches of the type shown on Fig. 1. 


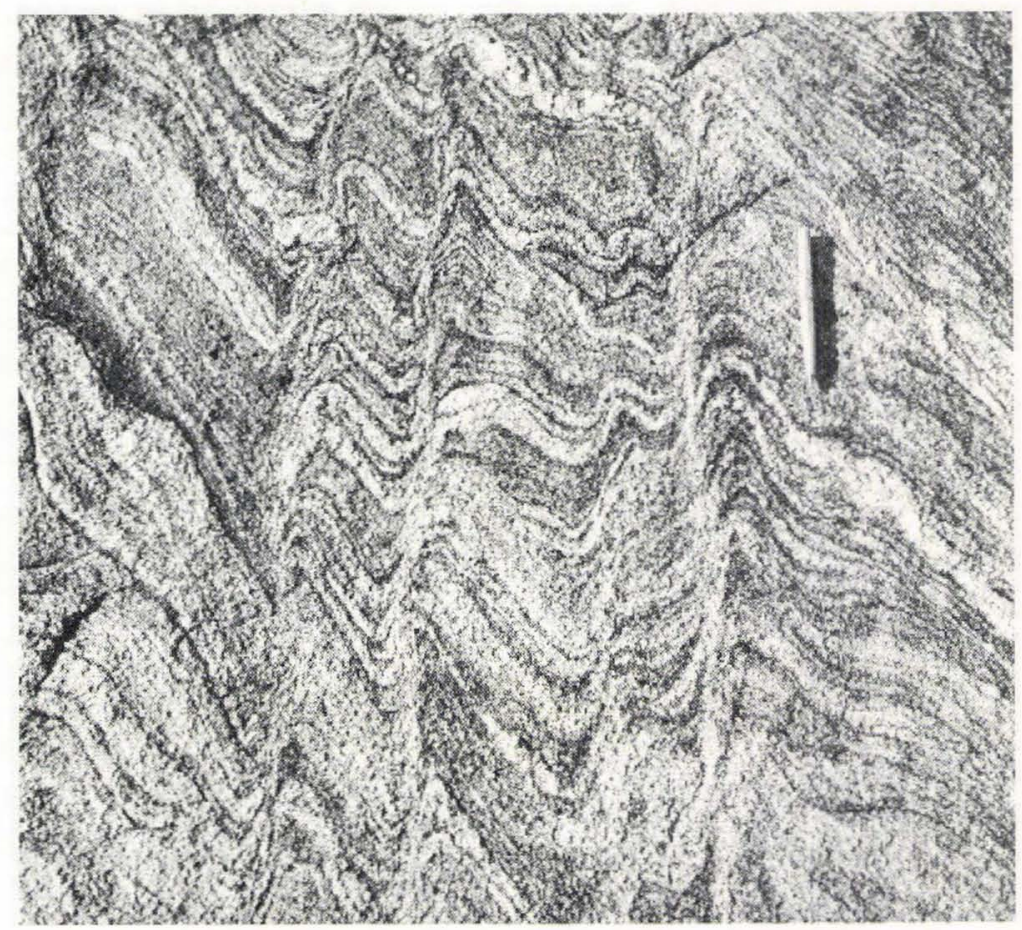

Fig. 4. Grædefjord gneiss showing pegmatite banding formed by intense deformation of irregular leucocratic veins of the type shown on Fig. 2. The pegmatite banding is folded by small $\mathrm{F}_{3}$ folds, each with a steep attenuated limb and flat-lying less deformed limb.

sthene as the main mafic mineral. The main regional differences in appearance of the Grædefjord gneiss are the result of different deformation histories and intensities. In some places a melanocratic variety occurs with similar grain size and relict porphyritic texture but with colour index 40 and with hornblende as the main mafic mineral.

In the region as a whole the Grædefjord gneiss exceeds the layered anorthosites, amphibolites and metasediments in volume and was intruded into them as sub-concordant sheets and masses. Individual sheets are still preserved in the thickest amphibolite and anorthosite bodies, and throughout the rest of the region the granodiorite gneiss contains trains of inclusions of amphibolite, metasediments and anorthosite. Although individual inclusions are locally disorientated within an inclusion train, as a whole each train represents a separate strip of the pre-granodiorite stratigraphy of amphibolite, metasediment and anorthosite units.

The inclusions of metasediment are associated with patches of pink pegmatite-banded gneiss. These rocks are most abundant in the south-western part of the region, mapped in 1971, where it was considered (Myers, 1973) that a large part of the pegmatite-banded gneisses enclosing the metasediments may also have been derived from supracrustal rocks. However metasediments and the pink pegmatite-banded gneiss are less abundant in other parts of the region mapped subsequently and thus, in the region as a whole, only a small part of the gneisses appears to be derived from supracrustal rocks. The distinctive 
pink pegmatite-banded gneiss which locally encloses the metasediments may have been derived either from rocks primarily associated with the metasediments or as a contact facies of the metasedimentary inclusions in the Grædefjord granodiorite gneiss.

\section{Ilivertalik porphyritic granite complex}

Part of this complex was first recognised by Kornerup (1879) on the mountain of Ilivertalik just north of Midgård, and was further described and named by Kalsbeek \& Myers (1973). It consists of a suite of biotite, hornblende and hypersthene bearing granites characterised by augen of potash feldspar $1-2 \mathrm{~cm}$ long, derived from primary phenocrysts (fig. 5).

Around inner Grædefjord it forms three thick sheets separated by Grædefjord granodiorite gneiss (Plate 1). Numerous small and thin sheets occur for $3 \mathrm{~km}$ to the south and cut across folded pegmatite-banded Grædefjord gneiss with inclusions of amphibolite, metasediments and anorthosite. The three large sheets have sharp contacts which are sub-concordant with the lithological layering of the inclusions in the Grædefjord gneiss.

The three sheets of Ilivertalik granite form prominent mountain ridges; the southernmost sheet is named after the mountain of Sermitsiaq, the middle sheet after the mountain of Umîvit, and the northern sheet after the pinnacle of Kuit qavata kingingnera. All three sheets are fairly homogeneous and are almost devoid of inclusions. The Umîvit and Sermitsiaq sheets are similar with densely packed potash feldspar phenocrysts, whereas in the Kuit qavata kingingnera sheet the phenocrysts are less densely packed and lie in a

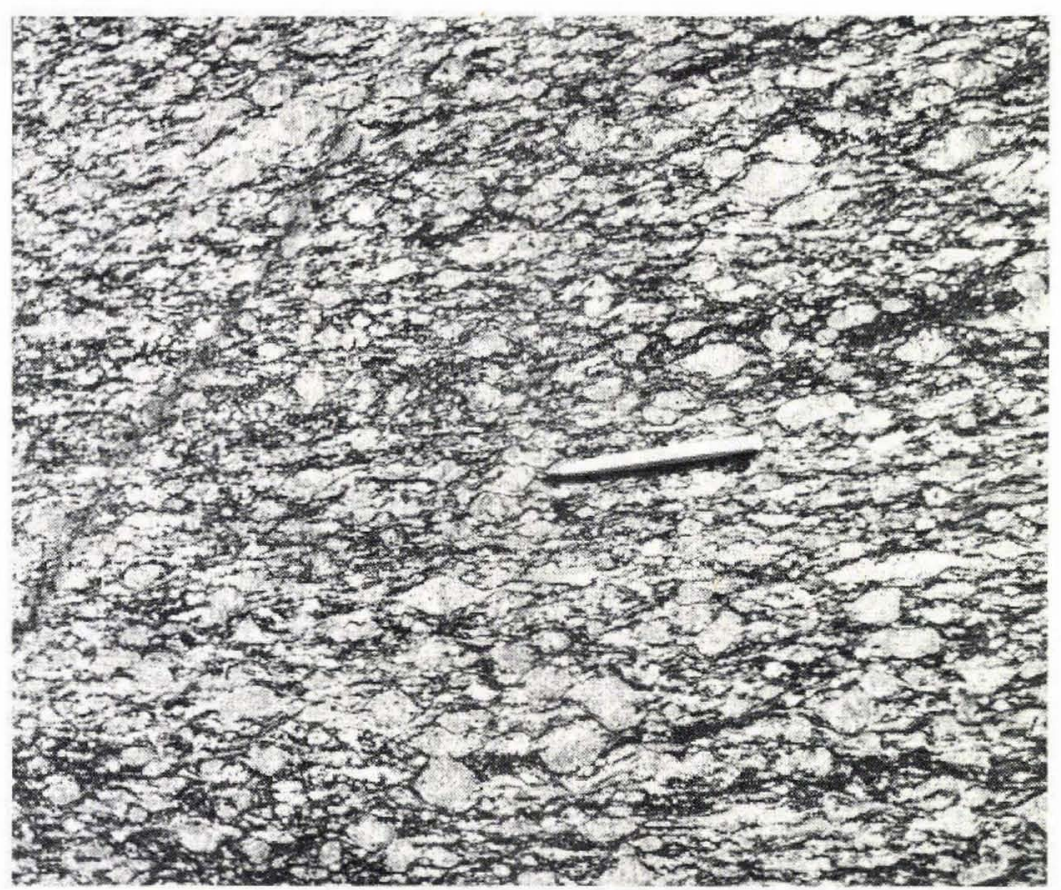

Fig. 5. Ilivertalik augen granite showing deformed igneous phenocrysts of potash feldspar. 
coarser grained matrix. Biotite forms the chief mafic mineral in both sheets with smaller amounts of epidote. In the west the sheets also contain hypersthene.

In general the Ilivertalik granite is strongly deformed and is an augen granite with linear and/or planar fabrics of variable intensity. Where it is undeformed it contains zoned potash feldspar laths up to $5 \mathrm{~cm}$ long which have no preferred orientation. With increasing deformation the phenocrysts are progressively rounded and their grain size is reduced by recrystallisation and redistribution of the material of the outer part of the phenocrysts.

The Umîvît sheet is made up of two facies with colour indices 5 and 2. In general the darker facies lies to the south and the lighter facies to the north. Locally sharp contacts are seen between them and the lighter facies veins the darker facies but in many places the contact is gradational. The darker facies contains a few inclusions or dismembered primary layers of a third, more melanocratic facies with up to $50 \%$ hornblende. In some places this melanocratic facies is associated with troughs which are layered by compositional gradations from homblende-rich $(50 \%)$ to mafic-free layers of quartz and feldspar. The consistent orientation of the composition grading suggests that the lighter facies to the north originally lay on top of the darker facies to the south.

Layered sheets of metadiorite and metatonalite up to $100 \mathrm{~m}$ thick occur both within the Ilivertalik granite and in the adjacent granodiorite gneisses, parallel with the margin of the granite sheets. They are spatially and temporally associated with the Ilivertalik granite

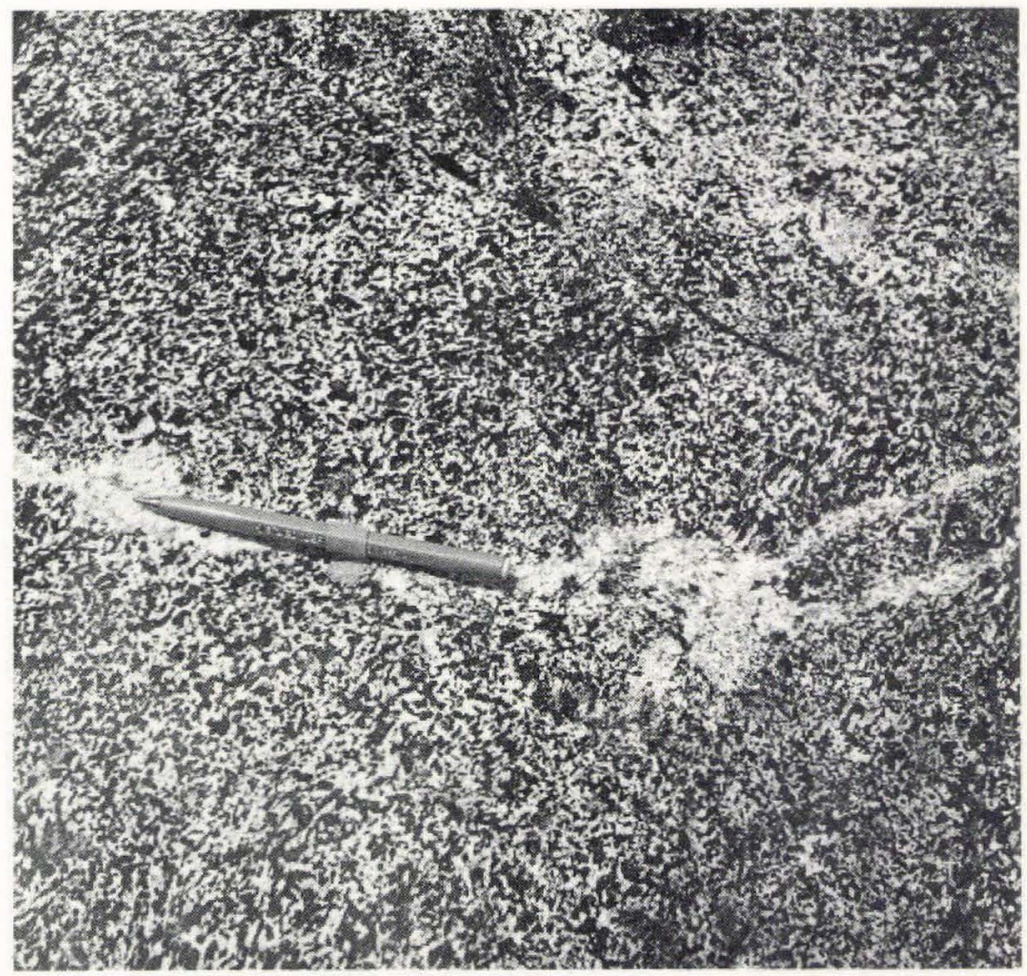

Fig. 6. Relict sub-ophitic texture in the centre of a pillowed hornblende diorite dyke in Ilivertalik augen granite. 
complex as late intrusions. The sheets are compositionally layered from leucocratic to melanocratic by variations in the proportion of plagioclase, hornblende, diopside and hypersthene. In some places relict igneous textures are preserved (fig. 6). Some sheets contain an ultramafic layer near their centre which is an olivine-hypersthene-magnetite cumulate. On one side these layers grade into rusty weathering metadiorite, rich in metal sulphides. Poorly-marked mineral graded layers in some parts of the sheets suggest that the sulphide-rich horizon originally lay on top of the ultramafic layer. The sheets were intruded soon after the emplacement of the porphyritic granite and in some places they broke up into trains of pillows and were back-veined by the granite. The pillowed fragments are finer grained and derived from thinner sheets than the major layered sheets and they possess fine-grained margins $1 \mathrm{~cm}$ thick.

The granite sheet of Kuit qavata kingingnera also contains partly assimilated large fragmented masses of an older diorite-tonalite body which is probably the oldest intrusion of the Ilivertalik granite complex.

\section{Qánguartoq granite, granodiorite and tonalite gneiss}

The Qánguartoq gneiss (Myers, 1973) occurs throughout the region as sheets and irregular shaped masses which cut across the Ilivertalik granite and its associated dioritetonalite sheets, and across amphibolite dykes which cut the older Grædefjord granodiorite gneiss (fig. 7). In the south it cuts across amphibolite-banded gneiss (Naujât gneiss; Myers, 1973) which can be traced eastwards, with progressive decrease in deformation state, into amphibolite net-veined by the Grædefjord granodiorite gneiss.

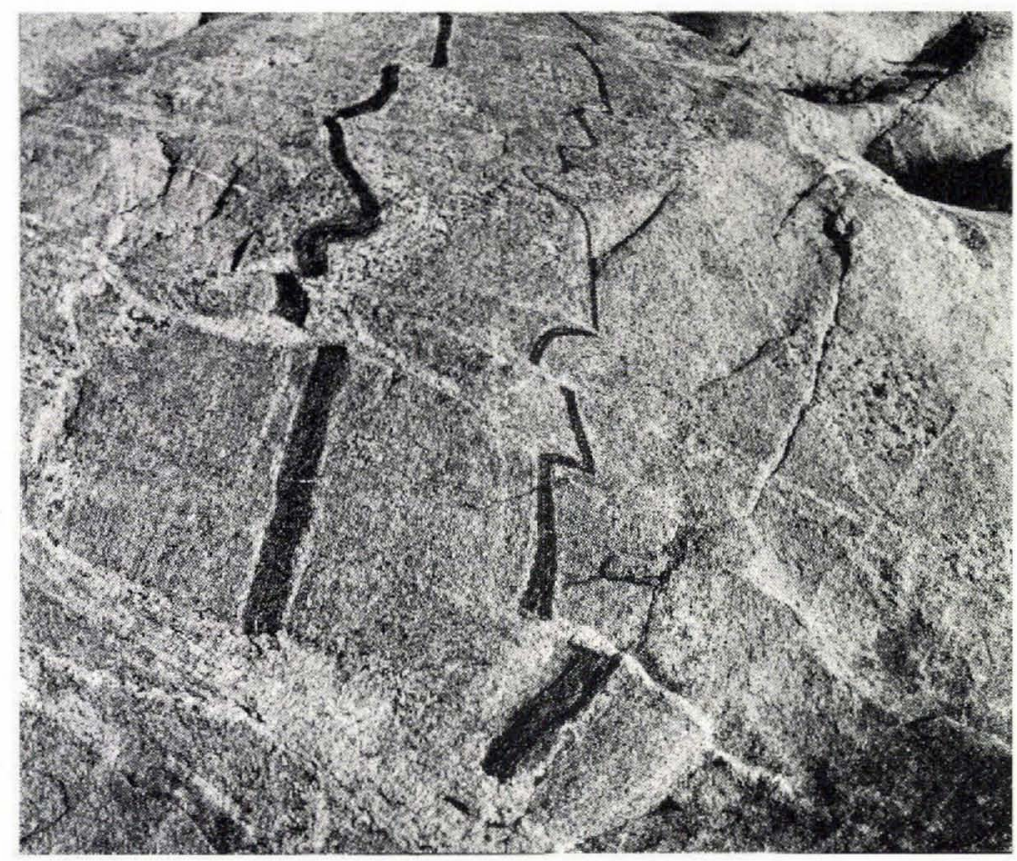

Fig. 7. Amphibolite dykes cutting little deformed Grædefjord granodiorite gneiss with relict igneous texture and primary pegmatitic patches. 


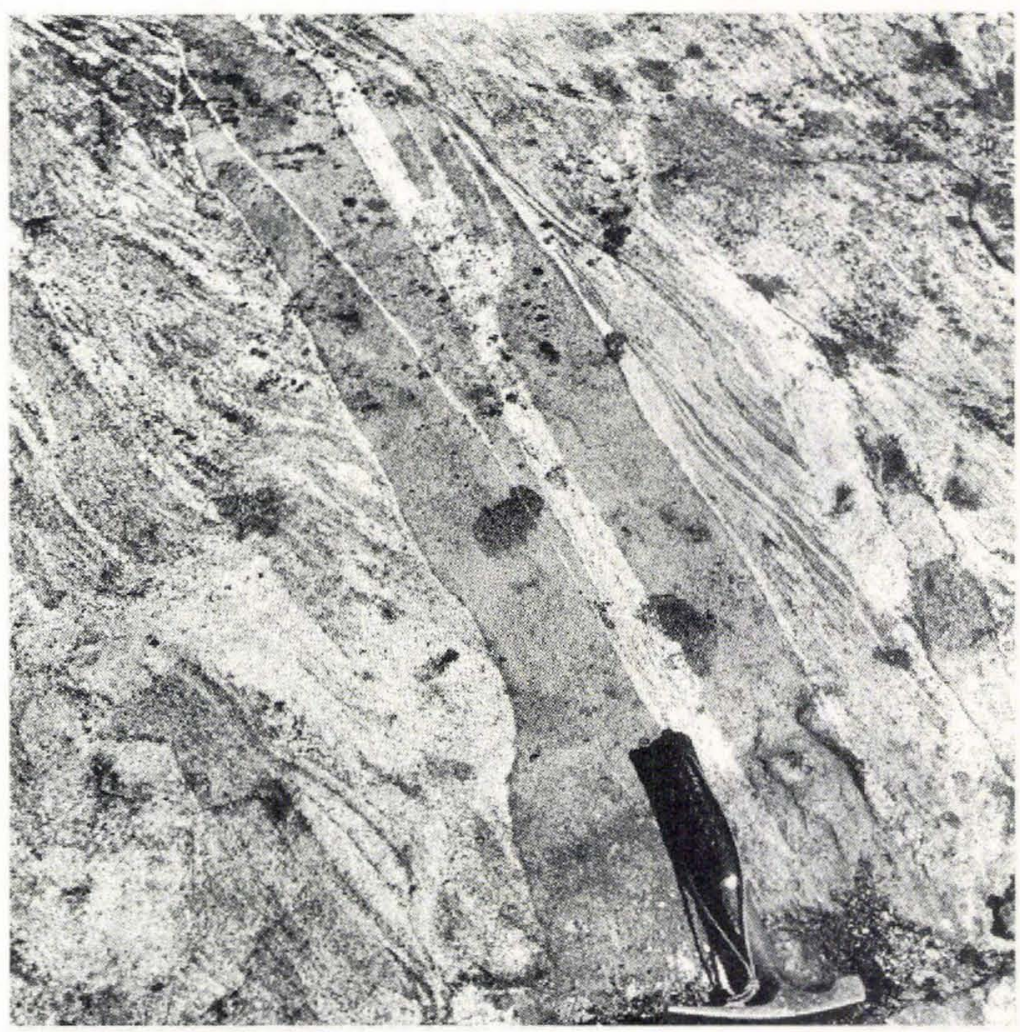

Fig. 8. Qánguartoq tonalite dykes cutting strongly deformed Grædefjord gneiss.

It is generally strongly deformed and is a pegmatite-banded gneiss made up of quartz, plagioclase, potash feldspar and biotite with accessory allanite, epidote and apatite. Within the Majorqap qâva anorthosite outcrop it also contains garnet. It is generally granite in composition but locally occurs as granodiorite and tonalite. The tonalites form small irregular shaped bodies and dykes (fig. 8) which are scattered throughout the region and consist of plagioclase, hornblende, biotite, and quartz.

In some places it can be seen that some Qánguartoq gneiss was intruded during the earliest stage of the $\mathrm{F}_{2}$ deformation which formed the main structural grain of the region, whereas in other places similar tonalitic dykes post-date the $\mathrm{F}_{2}$ deformation.

\section{Major deformation episodes}

The major episodes of deformation formed the main regional fold structures $\mathrm{F}_{1}-\mathrm{F}_{3}$ described by Kalsbeek \& Myers (1973). Gravity-stratified units within the anorthosites and amphibolites provide primary way-up criteria and form a datum for the regional fold chronology. The Grædefjord granodiorite gneiss was probably intruded before the $F_{1}$ isoclinal syncline seen in the Majorqap qâva anorthosite outcrop. On a small scale it can be seen that the anorthosites and amphibolites were already repeatedly deformed before 
the intrusion of the granodiorites and similarly the granodiorites were deformed before intrusion of the Ilivertalik granite complex.

The Ilivertalik and Qánguartoq granites were both deformed by the $F_{2}$ deformation which formed major tight and isoclinal folds with steep southerly dipping axial surfaces which trend east-west. $F_{2}$ fold axes are generally flat-lying where they are not reorientated by $\mathrm{F}_{3}$ folds and are locally associated with a parallel rodding fabric. The $\mathrm{F}_{2}$ deformation was generally very intense throughout the region, it emphasised the pre-existing banding and reduced the pre-existing grain sizes. Most of the region recrystallised in amphibolite facies. Low deformation zones form long narrow lenticular outcrops parallel with the axial surfaces of the $F_{2}$ folds. Deformation was especially intense at the margins of the Ilivertalik granite and the Majorqap qâva anorthosite outcrop where recrystallisation of the granite and granodiorite gneisses was unable to keep pace with the deformation and they were reduced to blastomylonite.

The $\mathrm{F}_{2}$ deformation post-dates the intrusion of the Ilivertalik granite and associated tonalite-diorite sheets, but was contemporary with intrusion of much of the Qánguartoq granite and granodiorite gneiss. Some Qánguartoq tonalite intrusions outlasted the $F_{2}$ deformation.

The $F_{3}$ deformation post-dates the intrusion of the tonalite dykes and formed large and small scale folds with steep axial surfaces striking NW-SE and with fold axes plunging to the SE. The folds are made up of steep, strongly deformed, attenuated limbs and shorter, less deformed, flat-lying limbs (fig. 4). The plunge of the fold axes varies according to the pre-existing dip of the layering of the gneiss complex but is generally moderate to low. A rodding fabric occurs throughout the region parallel with these fold axes. In general it is strongly marked but its intensity is variable and appears to be independent of both its position relative to major $F_{3}$ folds and to the local intensity of small $F_{3}$ fold development. Pegmatites were locally emplaced in the steep attenuated limbs of these folds.

During the $\mathrm{F}_{3}$ deformation amphibolite facies mineral assemblages developed throughout most of the region except in the west near Midgård where hornblende granulite facies assemblages were formed. The style of $\mathrm{F}_{3}$ folds also reflect the westward increase in metamorphic grade; the steep attenuated limbs of $\mathrm{F}_{3}$ folds are replaced westwards by shear zones and then by faults as Midgård is approached, showing a steady westward decline in the ductility of the gneisses, amphibolites and anorthosites, associated with hotter and drier metamorphism.

\section{References}

Kalsbeek, F. \& Myers, J. S. 1973: The geology of the Fiskenæsset region. Rapp. Grønlands geol. Unders. 51, 5-18.

Kornerup, A. 1879: Geologiske Iagttagelser fra Vestkysten af Grønland $\left(62^{\circ} 15^{\prime}-64^{\circ} 15^{\prime}\right.$ N. B.). Meddr Grønland 1, 77-139.

Myers, J. S. 1973: Field evidence concerning the origin of early Precambrian gneisses and amphibolites in part of the Fiskenæsset region. Rapp. Grønlands geol. Unders. 51, 19-22. 